\title{
Synthesis of 2,4-Disubstituted Imidazoles via Nucleophillic Catalysis
}

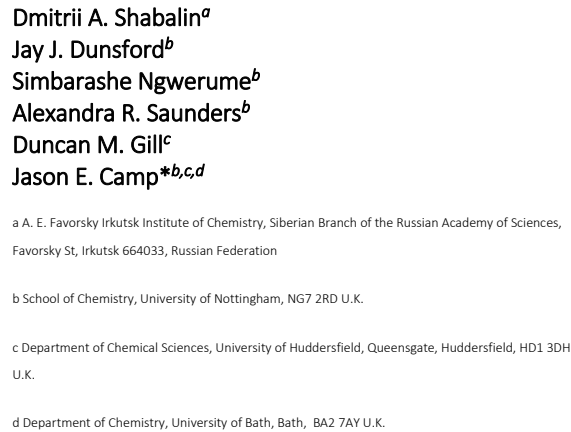

j.e.camp@hud.ac.uk

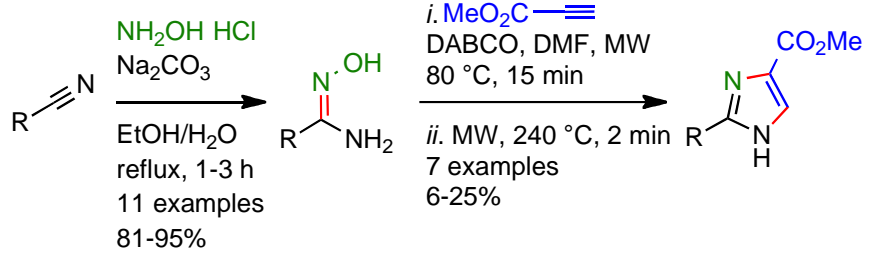

Due to our interest in the development of novel heterocyclic dyes for solar cells, an expedient synthesis to 2-aryl-4-ester substituted $1 H$-imidazoles was sought. ${ }^{12}$ Building upon our work on the synthesis of highly substituted pyrroles from the reaction of ketoximes and activated alkynes catalyzed by both noble metals and via nucleophilic catalysis methods, 13,14 we felt that a similar approach could be taken for the synthesis of imidazoles. Herein we report the findings from the study, including the development of a rapid, one-pot, nucleophilic catalysis approach to 2,4-disubstituted imidazoles from the reaction of a variety of amidoximes and electron-deficient alkynes.

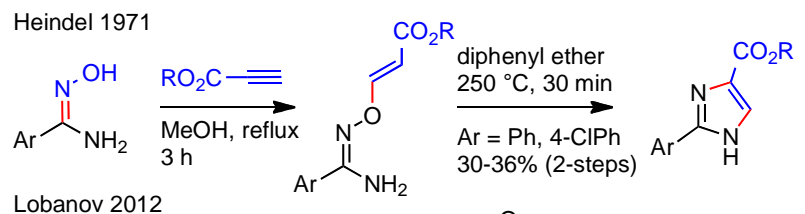
methods for the synthesis of imidazoles is both highly topical and necessary. ${ }^{6}$ One underutilized method for their synthesis is from the reaction of amidoximes with electron-deficient alkynes (Scheme 1).7 Heindel and Chun showed that arylamidoximes could be reacted with activated alkynes to form $O$ vinylamidoximes, which could subsequently be thermally rearranged into $\mathrm{NH}$-imidazoles with an aryl group at the 2 position and an ester moiety at the 4-position (Scheme 1). ${ }^{8 a}$ These functional handles would be useful for further synthetic manipulations and this disconnection provided a convergent way to form two $\mathrm{C}-\mathrm{N}$ bonds. Unfortunately, only imidazoles containing either a benzene or 4-chlorobenzene moiety at the two position have been synthesized using this protocol. ${ }^{8}$ More recently, Lobanov and co-workers examined the reaction of alkyl amidoximes and electron deficient alkynes. In contrast to the previous work, only the 4-acylpyrroles were isolated. ${ }^{9}$ Finally, Zhong and co-workers reacted arylamidoximes with the electron-deficient alkyne dimethylacetylene dicarboxylate (DMAD) under microwave irradiation to afford pyrimidones. ${ }^{10,11}$

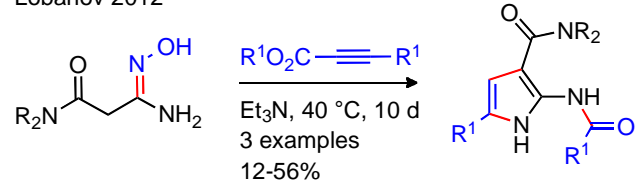

Zhong 2006

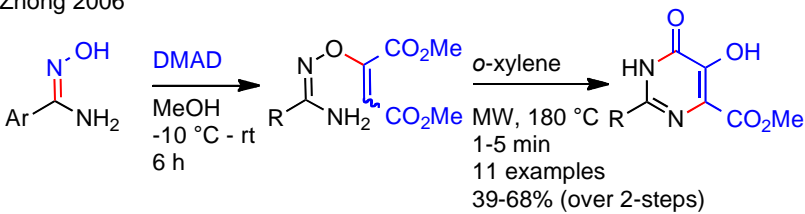

This work

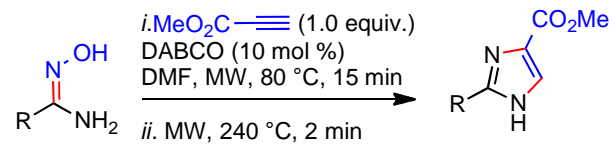

Scheme 1. Reaction of amidoximes with electron deficient alkynes

To begin, the formation of $O$-vinylamidoximes $\mathbf{3}$ from amidoximes 2 was investigated. It was anticipated that a solvent 
capable of reaching high temperatures in a microwave would be needed to ultimately synthesis imidazoles, so the initial focus was on the use of dimethylformamide (DMF). ${ }^{15} \mathrm{~A}$ variety of nucleophilic catalysts and bases were screened for their ability to promote the formation of the desired $O$-vinylamidoxime 3 . Reaction of phenylamidoxime 2a with methyl propiolate in the presence of nucleophilic catalysts 1,4-diazabicyclo[2.2.2] octane (DABCO), triphenylphosphine $\left(\mathrm{PPh}_{3}\right)$ and 4dimethylaminopyridine (DMAP) at $80{ }^{\circ} \mathrm{C}$ for 10 minutes in DMF under microwave heating afforded the desired $O$ vinylamidoxime 3a in good to excellent yields (Table 1, entries 1-3). In contrast, the use of bases such as 1,8diazabicyclo[5.4.0] undec-7-ene (DBU) and pyridine, only afforded $O$-vinylamidoxime $\mathbf{3 a}$ in moderate yield (Table 1 , entries 4-6). It was found that adding 50 to $100 \mathrm{~mol} \%$ of triethylamine $\left(\mathrm{Et}_{3} \mathrm{~N}\right)$ to the reaction mixture also resulted in formation of $O$-vinylamidoxime $\mathbf{3 a}$ in good yield (Table 1 , entries 7-8). Unfortunately, due to potential thermal degradation of triethylamine it was unsuitable for the second step of the process. Only starting material was recovered in the absence of a nucleophilic catalyst or base (Table 1, entry 9).

Table 1. Optimization of $O$-vinylamidoxime formation.

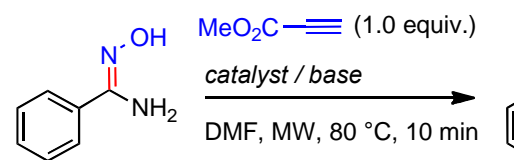

2a

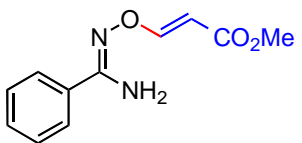

$3 a$

\begin{tabular}{llll}
\hline Entry & Catalyst / Base & Mol \% & Yield $^{a}(\%)$ \\
\hline $\mathbf{1}$ & DABCO $^{\circ}$ & 10 & 90 \\
$\mathbf{2}$ & $\mathrm{PPh}_{3}$ & 10 & 81 \\
$\mathbf{3}$ & DMAP $_{\mathbf{4}}$ & 10 & 61 \\
$\mathbf{4}$ & DBU & 10 & 17 \\
$\mathbf{5}$ & Pyridine & 10 & 37 \\
$\mathbf{6}$ & Pyridine & 50 & 15 \\
$\mathbf{7}$ & Et $_{3} \mathrm{~N}$ & 50 & 71 \\
$\mathbf{8}$ & $\mathrm{Et}_{3} \mathrm{~N}$ & 100 & 80 \\
$\mathbf{9}$ & - & & $0^{b}$ \\
\hline
\end{tabular}

${ }^{a}$ Isolated yields. ${ }^{b}$ Only starting material was recovered.

With a better understanding of the conditions required to convert amidoximes to $O$-vinylamidoximes and then onto imidazoles ( $c f$. Table S1) the feasibility of a convergent, one-pot method was undertaken (Table 2). The optimization process was conducted using ${ }^{19} \mathrm{~F}$ NMR analysis of the crude reaction mixture to determine conversion of the starting material and distribution of the products. To begin the study, 4-fluoro- $N$ 'hydroxybenzimidamide (2b) was converted to methyl 3$\{[$ (amino(4-fluorophenyl)methylene)amino]oxy\}acrylate (3b) using the conditions identified previously ( $c f$. Table 1 ). Having shown the amenability of this substrate to the $O$-vinylation protocol, the one-pot conversion of amidoxime $\mathbf{2 b}$ to imidazole $\mathbf{4 b}$ was undertaken. Subjection of amidoxime $\mathbf{2 b}$ to a two-stage microwave protocol led to its initial conversion to $O$ vinylamidoxime $\mathbf{3 b}$, which was subsequently rearranged at high temperature to imidazole $\mathbf{4 b}$ (Table 2). Running the second stage of the reaction at $200{ }^{\circ} \mathrm{C}$ for between 5 and 45 minute gave moderate yields of the desired imidazole $\mathbf{4 b}$ (Table 2, entries 24). In order to minimize degradation due to exposure of the substrate to high temperatures, the second stage of the reaction was run for five minutes over the temperature range of $200^{\circ} \mathrm{C}$ to $260^{\circ} \mathrm{C}$ in $20^{\circ} \mathrm{C}$ increments (Table 2, entries 4-7). It was found that $240{ }^{\circ} \mathrm{C}$ gave the highest NMR yield of imidazole $\mathbf{4 b}$. Experiments that investigated the timings of the two stages of the reaction showed that the best isolated yield of imidazole $\mathbf{4 b}$ could be obtained when stage 1 was run for 15 minutes and stage two for 2 minutes, at $80{ }^{\circ} \mathrm{C}$ and $240{ }^{\circ} \mathrm{C}$ respectively. (Table 2, entries 8-13)

Table 2. Optimization of imidazole formation.

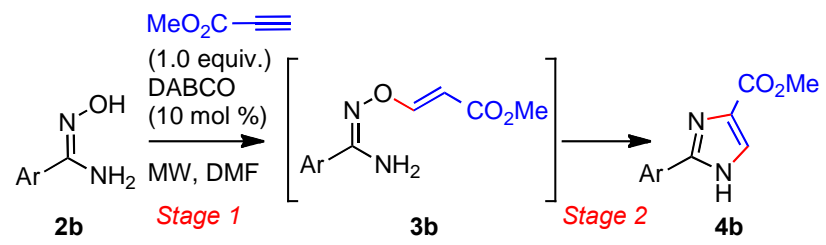

$\mathrm{Ar}=4$-fluorobenzene

\begin{tabular}{|c|c|c|c|}
\hline Entry & Stage $1^{a}$ & Stage $2^{a}$ & Yield \\
\hline 1 & $80^{\circ} \mathrm{C}, 10 \mathrm{~min}$ & - & $(82)^{c}$ \\
\hline 2 & $80^{\circ} \mathrm{C}, 15 \mathrm{~min}$ & $200^{\circ} \mathrm{C}, 45 \mathrm{~min}$ & 14 \\
\hline 3 & $80^{\circ} \mathrm{C}, 10 \mathrm{~min}$ & $200^{\circ} \mathrm{C}, 30 \mathrm{~min}$ & 17 \\
\hline 4 & $80^{\circ} \mathrm{C}, 10 \mathrm{~min}$ & $200^{\circ} \mathrm{C}, 5 \mathrm{~min}$ & 15 \\
\hline 5 & $80^{\circ} \mathrm{C}, 10 \mathrm{~min}$ & $220^{\circ} \mathrm{C}, 5 \mathrm{~min}$ & 20 \\
\hline 6 & $80^{\circ} \mathrm{C}, 10 \mathrm{~min}$ & $240^{\circ} \mathrm{C}, 5 \mathrm{~min}$ & 21 \\
\hline 7 & $80^{\circ} \mathrm{C}, 10 \mathrm{~min}$ & $260^{\circ} \mathrm{C}, 5 \mathrm{~min}$ & 12 \\
\hline 8 & $80^{\circ} \mathrm{C}, 10 \mathrm{~min}$ & $240^{\circ} \mathrm{C}, 0.5 \mathrm{~min}$ & 22 \\
\hline 9 & $80^{\circ} \mathrm{C}, 10 \mathrm{~min}$ & $240^{\circ} \mathrm{C}, 1 \mathrm{~min}$ & $(17)$ \\
\hline 10 & $80^{\circ} \mathrm{C}, 10 \mathrm{~min}$ & $240{ }^{\circ} \mathrm{C}, 10 \mathrm{~min}$ & 18 \\
\hline 11 & $80^{\circ} \mathrm{C}, 15 \mathrm{~min}$ & $240^{\circ} \mathrm{C}, 1 \mathrm{~min}$ & $(10)$ \\
\hline 12 & $80^{\circ} \mathrm{C}, 15 \mathrm{~min}$ & $240^{\circ} \mathrm{C}, 2 \mathrm{~min}$ & (19) \\
\hline 13 & $80^{\circ} \mathrm{C}, 15 \mathrm{~min}$ & $240^{\circ} \mathrm{C}, 5 \mathrm{~min}$ & (15) \\
\hline
\end{tabular}

$a$ Reactions were conducted under microwave irradiation $b$ Determined by ${ }^{19} \mathrm{~F}$ NMR with isolated yield in brackets. ${ }^{b}$ Yield of $O$-vinylamidoxime $\mathbf{3 b}$

Next, the synthesis of a variety of amidoximes from nitriles was investigated. After screening a variety of conditions, it was found that the method that worked best for the substrates of interest was to reflux aryl nitriles $\mathbf{1}$ in an ethanol:water (3:2 $\mathrm{v} / \mathrm{v}$ ) mixture containing hydroxylamine hydrogen chloride and sodium carbonate for 1-3 h. Using these conditions, a small library of amidoxime substrates was generated that included substituted aromatics $\mathbf{2 b} \mathbf{\mathbf { b }} \mathbf{2 h}$, heteroaromatics $\mathbf{2 i - 2} \mathbf{k}$ as well as a benzylic amidoxime $\mathbf{2 l}$ (Scheme 2). 
With optimal conditions in hand for the one-pot generation of substituted imidazoles from amidoxime and activated alkynes (Table 2, Entry 12), the substrate scope and functional group tolerance of the protocol was investigated (Scheme 3).16 Thus, subjection of both neutral 2a and electron deficient aromatic amidoximes $\mathbf{2 b}-\mathbf{d}, \mathbf{2 f}$ to the two-stage microwave protocol afforded the desired imidazoles $\mathbf{4 a - d}, \mathbf{4 f}$ in moderate yield. Importantly, the reaction could be run on a $4.3 \mathrm{mmol}$ scale without a decrease in isolated yield of the desired imidazole $\mathbf{4 d}$. Interestingly, subjection of the dimethylaniline compound $\mathbf{2 e}$ to the standard reaction conditions resulted in tar formation (vide infra). In addition, electron rich benzene derivatives $\mathbf{2} \mathbf{g}$ and $\mathbf{2 h}$ also afforded the desired imidazole $\mathbf{4 g}^{17}$ and $\mathbf{4 h}$ in moderate yield. Thus, the electronics of the system do not appear to play a significant role on the isolated yield. Furan-amidoxime $\mathbf{2} \mathbf{i}$ and

Scheme 2. Synthesis of substituted amidoximes 2
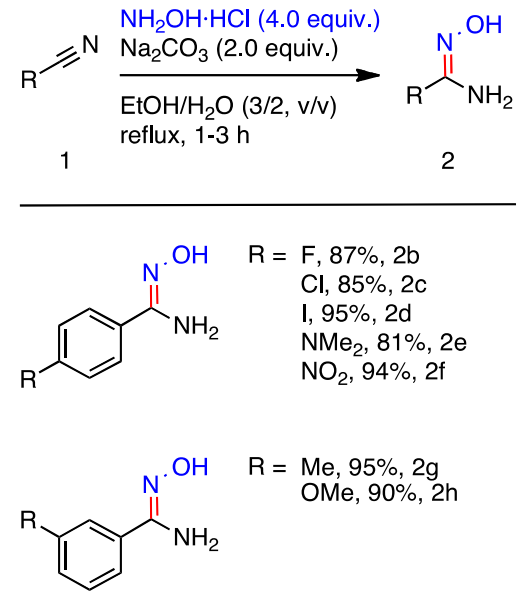

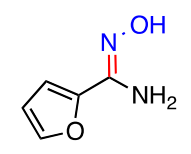

$90 \%, 2 i$<smiles>N/C(=N\O)c1ccc2[nH]ccc2c1</smiles>

$90 \%, 2 \mathrm{k}$

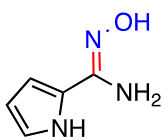

$83 \%, 2 \mathrm{j}$<smiles>N/C(Cc1ccccc1)=N/O</smiles>

$95 \%, 21$ pyrrole-amidoxime $\mathbf{2} \mathbf{j}$ were converted to imidazole $\mathbf{4 i}$ and $\mathbf{4} \mathbf{j}$, respectively, under the standard reaction conditions. Unfortunately, no imidazoles were isolated from the reactions of indole-amidoxime $\mathbf{2 k}$ and benzylic-amidoxime $\mathbf{2 l}$ with methylpropiolate. This was due to the formation of intractable tar like mixtures. In an attempt to improve the isolation / purification of the imidazoles, a tert-butylcarbonyl protecting group was installed on iodo-derivative $\mathbf{4 b}$ leading to BOCimidazole $\mathbf{5 b}$ in good yield (see ESI for details). Next, upon completion of the two stage imidazole formation protocol, ditert-butyl dicarbonate was added to the crude reaction mixture. Unlike our previous experience with $\mathrm{NH}$-pyrrole, in which the in situ protection of the basic nitrogen facilitated isolation, ${ }^{13 c}$ no improvement in isolated yield was observed for the imidazole compounds.

In summary, we have disclosed a convergent protocol for the synthesis of substituted imidazoles via a microwave assisted one-pot nucleophillic catalysis approach. Of note is the amenability of this method to the regioselective synthesis of 2,4disubstituted $\mathrm{NH}$-imidazoles. The functional group handles at the $\mathrm{C} 2$ and $\mathrm{C} 4$ positions should be amenable for further manipulations. The substrate scope of this disconnection was probed and expanded significantly from the two known aryl

\section{Scheme 3. One-pot synthesis of imidazoles 4 from} amidoximes 2
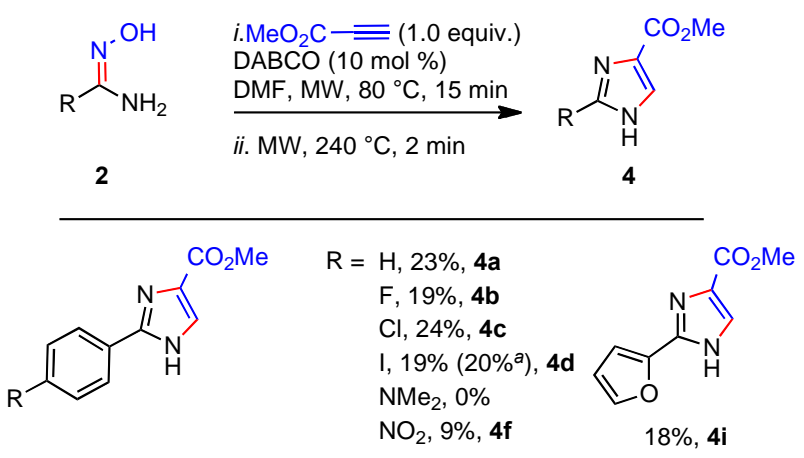<smiles>[R]c1cccc(-c2nc(C(C)=O)c[nH]2)c1</smiles><smiles>CC(=O)c1c[nH]c(-c2ccc3[nH]ccc3c2)n1</smiles>
$\mathrm{R}=\mathrm{Me}, 25 \%, \mathbf{4 g}$ OMe, $21 \%, 4 h$<smiles>CC(=O)c1c[nH]c(-c2ccc[nH]2)n1</smiles><smiles>CC(=O)c1c[nH]c(Cc2ccccc2)n1</smiles>

$6 \%, 4 \mathbf{j}$

${ }^{a}$ reaction was run on a $4.3 \mathrm{mmol}$ scale

derivates that have been reported in the literature (aryl group = benzene and 4-chlorobenzene). In addition, the isolated yields compare favourably to the related two-step process. To the best of our knowledge this is the first example of a catalytic one-pot method for the direct synthesis of imidazoles from amidoximes and activated alkynes and we anticipate that it will find wide application due to its simple operating procedure.

\section{Acknowledgment}

We would like to gratefully acknowledge the financial support received from the Engineering and Physical Sciences Research Council (EPSRC, postdoctoral associateship for JJD through First-Grant EP/J003298/1), a Pfizer summer research fellowship (ARS), the University of Nottingham (SN) and a Royal Society of Chemistry mobility grant (DAS).

\section{Supporting Information}

Yes

\section{References and Notes}

\footnotetext{
${ }^{1}$ For recent example, see: (a) S. Jeanmart, J. Gagnepain, P. Maity, C. Lamberth, F. Cederbaum, R. Rajan, O. Jacob, M. Blum and S. Biere, Bioorg. Med. Chem., 2018, 26, 2009-2016. (b) S. Naureen, F. Chaudhry, M. A. Munawar, M. Ashraf, S. Hamid and M. A. Khan, Bioorg. Chem., 2018, 76, 365-369. (c) Y. Hu, Y. Shen, X. Wu, X. Tu and G.-X. Wang, Eur. J. Med. Chem., 2018, 143, 958-969. (d) B. Kuzu, M. Tan, P. Taslimi, İ. Gülçin, M. Taşpınar and N. Menges, Bioorg. Chem., 2019, 86, 187-196.
} 
${ }^{2}$ For recent example, see: (a) M. S. Roy, X. Meg, K. Koda, S. Rasapalli, D. Gout, C. J. Lovely, Tetrahedron Lett. 2019, 60, 979-982. (b) Z. Jin, Nat. Prod. Rep. 2011, 28, 1143-1191. (c) D. P. O’Malley,K. Li, M. Maue, A. L. Zografos, P. S. Baran, J. Am. Chem. Soc. 2007, 129, $4762-4775$. ${ }^{3}$ For recent example, see: (a) K. Dhanunjayarao, V. Mukundam, R. V. R. N. Chinta and K. Venkatasubbaiah, J. Organomet. Chem., 2018, 865, 234-238. (b) S. A. Khan, A. M. Asiri, A.-A. M. Al-Dies, O. I. Osman, M. Asad and M. E. M. Zayed, J. Photochem. Photobiol. A, 2018, 364, 390-399. (c) A. Hariharan, S. Kumar, M. Alagar, K. Dinakaran and K. Subramanian, Polym. Bull. 2018, 75, 93-107.

${ }^{4}$ For recent example, see: (a) C. Wang, Y. Zhou, C. Xu, X. Zhao, J. Li and Q. Ren, Int. J. Hydrogen Energy, 2018, 43, 20739-20749. (b) S. Yang, Q. Zhang, Y. Hu, G. Ding, J. Wang, S. Huo, B. Zhang and J. Cheng, Mat. Lett., 2018, 216, 127-130. (c) E. Elanthamilan, S. Rajkumar, R. Rajavalli and J. P. Merlin, New J. Chem., 2018, 42, 10300-10308.

${ }^{5}$ For recent examples, see: (a) J. A. Castro-Osma, J. Martínez, F. de la Cruz-Martínez, M. P. Caballero, J. Fernández-Baeza, J. Rodríguez-López, A. Otero, A. Lara-Sánchez and J. Tejeda, Catal. Sci. Technol., 2018, 8, 1981-1987. (b) M. Gholinejad, R. Bonyasi, C. Najera, F. Saadati, M. Bahrami and N. Dasvarz, ChemPlusChem, 2018, 83, 431-438.

${ }^{6}$ For recent examples of imidazole syntheses, see: (a) S. Sundar and R. Rengan, Org. Biomol. Chem., 2019, 17, 1402-1409. (b) M. Beuvin, M. Manneveau, S. Diab, B. Picard, M. Sanselme, S. R. Piettre, J. Legros and I. Chataigner, Tetrahedron Lett., 2018, 59, 4487-4491. (c) J. Cai, H. Bai, Y. Wang, X. Xu, H. Xie and J. Liu, Chem. Commun., 2019, 55, 3821-3824. (d) J. O. Strelnikova, N. V. Rostovskii, G. L. Starova, A. F. Khlebnikov and M. S. Novikov, J. Org. Chem., 2018, 83, 11232-11244.

${ }^{7}$ For the synthesis and reactivity of electron rich $O$-vinylamidoximes, see: Trofimov, B. A.; Schmidt, E. Y.; Mikhaleva, A. I.; Vasil'tsov, A. M.; Afonin, A. V., Mendeleev Comm. 2000, 10, 29-30. (b) Trofimov, B. A.; Schmidt, E. Y.; Vasil'tsov, A. M.; Mikhaleva, A. I.; Zaitsev, A. B.; Morozova, L. V.; Gorshkov, A. G.; Henkelmann, J.; Arndt, J.-D., Synthesis 2001, 16, 2427-2430.

${ }^{8}$ (a) Heindel, N. D.; Chun, M. C., Tetrahedron Lett. 1971, 18, 1439-1440. (b) Kudo, N.; Furuta, S.; Taniguchi, M.; Endo, T.; Sato, K. Chem. Pharm. Bull. 1999, 47, 857-868.

${ }^{9}$ Pivneva, E. E.; Galenko, A. V.; Dar'in, D. V.; Lobanov, P. S., Chem. Heterocycl. Comp. 2012, 48, 942-947.

${ }^{10}$ Zhong, Y.-L.; Zhou, H.; Gauthier, D. R. Jr.; Askin, D., Tetrahedron Lett. 2006, 47, 1315-1317.

${ }^{11}$ For related work on the synthesis of pyrimidones via amidoximes, see: (a) Culbertson, T. P., J. Heterocycl. Chem. 1979, 16, $1423-1424$.

12 (a) Black, F. A; Wood, C. J.; Ngwerume, S.; Summers, G. H.; Clark, I. P.; Towrie, M.; Camp, J. E.; Gibson, E. A., Faraday Discuss. 2017, 198, 449-461. (b) Summers, G. H.; Lowe, G.; Lefebvre, J.-F.; Ngwerume, S.; Bräutigam, M.; Dietzek, B.; Camp, J. E.; Gibson, E. A., ChemPhysChem 2017, 18, 406-414.

13 (a) Ngwerume, S.; Lewis, W.; Camp, J. E., J. Org. Chem. 2013, 78, 920-934. (b) Ngwerume, S.; Camp, J. E., Chem. Comm. 2011, 47, 18571859. (c) Ngwerume, S.; Camp, J. E., J. Org. Chem. 2010, 75, 6271-6274. (d) Britton, J.; Camp, J. E., Chem. Today 2012, 30, 6-8.

${ }^{14}$ For recent examples of nucleophilic catalysis, see: (a) Chung, W.; Lindovská, P.; Camp, J. E., Tetrahedron Lett. 2011, 52, 6785-6787. (b) Toda, Y.; Sakamoto, T.; Komiyama, Y.; Kikuchi, A.; Suga, H., ACS Catal. 2017, 7, 6150-6154. (c)Tamaki, A.; Kojima, S.; Yamamoto, Y. J. Org. Chem. 2016, 81, 8710-8721. (d) Fu, G. C., Acc. Chem. Res. 2000, 33, 412-420. (d) Lester, R. P.; Camp, J. E., ACS Sustainable Chem. Eng., 2013, $1,545-548$.

${ }^{15}$ Unfortunately, the commercially available bioalternative solvent Cyrene ${ }^{\mathrm{TM}}$ could not be used at the requisite elevated temperatures due to its thermal instability, see: (a) Bousfield, T. W., Pearce, K. P. R.; Nyamini, S. B.; Angelis-Dimakis, A.; Camp, J. E. Green Chem. 2019, 21, 36753681. (b) Camp, J. E. ChemSusChem 2018, 11, 3048-3055. (c) Mistry, L.; Mapesa, K.; Bousfield, T. W.; Camp, J. E. Green Chem. 2017, 19, 2123-2128. (d) Camp, J. E.; Nyamini, S. B.; Scott, F. J. RSC Med. Chem. 2020, Advance Article DOI:10.1039/C9MD00341J.

${ }^{16}$ General Proceedure: An oven dried microwave vial was loaded with the desired amidoxime 2 (0.66 mmol) and DABCO (7.4 mg, 0.066 $\mathrm{mmol})$, then methyl propiolate $(55 \mathrm{mg}, 0.66 \mathrm{mmol})$ in dry $N, N$-dimethylformamide $(3 \mathrm{~mL})$ was added under a nitrogen atmosphere. The reaction mixture was subjected to a two-stage microwave irradiation sequence (Stage 1: $80{ }^{\circ} \mathrm{C}, 15 \mathrm{~min} /$ Stage 2: $240{ }^{\circ} \mathrm{C}, 2 \mathrm{~min}$ ). The mixture was concentrated under reduced pressure, the residue dissolved in ethyl acetate $(20 \mathrm{~mL})$, washed with water $(2 \times 10 \mathrm{~mL})$ and dried over anhydrous $\mathrm{Na}_{2} \mathrm{SO}_{4}$. The residue after solvent evaporation was purified by flash column chromatography on silica gel (petroleum ether/ethyl acetate) to afford the desired imidazole 4.

${ }^{17}$ Methyl 2-(m-tolyl)-1H-imidazole-4-carboxylate (4g). General Procedure: Yield $35 \mathrm{mg}$ (25\%), yellow solid, mp $168-170{ }^{\circ} \mathrm{C} .{ }^{1} \mathrm{H}$ NMR (DMSO-d $): \delta 13.22(\mathrm{br} \mathrm{s}, 1 \mathrm{H}, \mathrm{NH}), 7.92(\mathrm{~s}, 1 \mathrm{H}, \mathrm{CH}), 7.87(\mathrm{~s}, 1 \mathrm{H}, \mathrm{Ar}), 7.81(\mathrm{~d}, J=7.6 \mathrm{~Hz}, 2 \mathrm{H}, \mathrm{Ar}), 7.37-7.33(\mathrm{~m}, 1 \mathrm{H}, \mathrm{Ar}), 7.21(\mathrm{~d}, J=7.6 \mathrm{~Hz}$, $2 \mathrm{H}, \mathrm{Ar}$ ), 3.78 (s, 3H, Me), 2.36 (s, 3H, Me). ${ }^{13} \mathrm{C}\left\{{ }^{1} \mathrm{H}\right\}$ NMR (DMSO-d 6 ): $\delta 162.8,147.2,138.0,129.7,129.7,128.7,126.1,122.7,51.1,21.03(2 \mathrm{C}$ missed). HRMS (ESI/Q-TOF) $m / z:[\mathrm{M}+\mathrm{H}]^{+} \mathrm{Calcd}$ for $\mathrm{C}_{12} \mathrm{H}_{13} \mathrm{~N}_{2} \mathrm{O}_{2} 217.0977$; Found 217.0970. 